\title{
A Critical Evaluation OF THE KOORI COURT DIVISION OF THE VICTORIAN MAgISTRATES' COURT
}

\author{
BRIDGET MCASEY
}

\begin{abstract}
[The Koori Court Division of the Magistrates' Court in Victoria has been in operation since 2002. This article seeks to assess its development and operation, with the perspective that the Division has the potential to address problems Aboriginal people face in the criminal justice system and society generally. The author takes the view, however, that to fulfil this potential, the Division's development and operation must function in a way that makes some effort to adjust the power imbalance between the Aboriginal and non-Aboriginal community, The author sees a critical approach to an evaluation of the Division as crucial, considering the background of treatment Aboriginal people have received at the hands of the criminal justice system and Australian society as a whole, and the negative impact of previous government policies.]
\end{abstract}

\section{INTRODUCTION}

The Koori Division of Victoria’s Magistrates' Court (the Division) currently operates as a permanent court under the jurisdiction of the Magistrates' Court, and has its origins in the Victorian Aboriginal Justice Agreement (VAJA). ${ }^{1}$ In many ways, it reflects an innovative and progressive approach to the problems Aboriginal people face in the legal system. The VAJA has its origins in the Royal Commission into Aboriginal Deaths in Custody (RCIADIC) ${ }^{2}$ and a desire by the Victorian Government to implement its recommendations. ${ }^{3}$ The Division is established by

\footnotetext{
* Law Graduate, The University of Melbourne. An earlier version of this article was submitted as part of a program of study undertaken for an LLB in the Faculty of Law, University of Melbourne. I would like to thank the anonymous referee for their helpful comments.

${ }^{1}$ Department of Justice, Victorian AbOriginal Justice AgreEment, available at

$<$ http://www.justice.vic.gov.au> (last visited Aug. 4, 2004).

${ }^{2}$ Id.

${ }^{3}$ DEPARTMENT OF Justice, Business Units: InDIGENOUS IsSUES, available at
} 
legislation, the Magistrates' Court (Koori Court) Act 2002 (Vic), although this legislation provided only a basic framework for its establishment, leaving the Division to "regulate its own procedure". ${ }^{4}$ This suggests that its procedures and practices would be able to develop over time and be modified as necessary. Koori Court Divisions of the Magistrates' Court are currently operating at Shepparton, Broadmeadows and most recently Warrnambool. ${ }^{5}$ This paper will focus on the Courts at Shepparton and Broadmeadows (with a bias towards Shepparton, which by virtue of it being the first Koori Court Division to operate, has served as the model for subsequent Koori Court Divisions). It is important to recognise the limitations of this as the Divisions are different from each other due to their geographical locations, the characteristics of the Koori ${ }^{6}$ community they serve and the personnel they are staffed by. A more complete evaluation of the Divisions would consider them all separately and comparatively. Unfortunately this is not possible here.

The structure of this paper will be to first give an outline of the legislative framework for the Division and how this has been translated procedurally (Part II). The procedure that is outlined will be expanded upon in later parts of the paper, using specific examples to assess the Division. The assessment is split into two broad categories which are labelled "development" (Part III) and "procedural or inpractice” (Part IV). The final section of the paper (Part V) will address and discuss some common criticisms of the Division. The "development" component is concerned with how the Division was set up, with regard paid to the VAJA, media reports, various sources evidencing the development process and the working committee at Shepparton which dealt with the "nuts and bolts"7 of the Division. In dealing with this category, the primary aim will be to assess whether there was sufficient consideration of the wants and needs of the Aboriginal community and the overriding issue of whether sufficient power was devolved to the Koori community in the formation of the Division in order for it to be truly responsive. Devolution of power and sufficient consideration of the wants and needs of the Koori community has the potential to rectify, or at least contribute to the rectification of, the discrimination, criminalisation ${ }^{8}$ and "years of mistreatment"9 of Aboriginal

$<$ http://www.justice.vic.gov.au> (last visited Aug. 5 2004); VICTORIAN ABORIGINAL JUSTICE FORUM, VICTORIAN IMPLEMENTATION REVIEW OF THE RECOMMENDATIONS FROM THE ROYAL COMMISSION INTO ABORIGINAL DEATHS IN CUSTODY (2004), on file with author.

${ }^{4}$ Magistrates' Court (Koori Court) Act, 2002 (Vic) and see also, Magistrates' Court (Judicial Registrars and Court Rules) Act 2005, s (2)(e) and (f) (Vic), which allows Magistrates to make rules of court with respect to "any matter relating to the practice and procedure of the Koori Court Division of the Court" and "the transfer of proceedings to and from the Koori Court Division of the Court" and the Children and Young Persons (Koori Court) Act, 2004 (Vic), which expands the Koori Court Division so that it can deal with children's matters.

${ }^{5}$ Another Koori Court Division is soon to begin operation at Mildura, in July 2005.

${ }^{6}$ The terms 'Aboriginal' and 'Koori' are both used in this paper. In general, the term 'Aboriginal people' will be used when referring to the Indigenous population Australia wide and 'Koori” will be used when referring to Victorian Indigenous people more specifically.

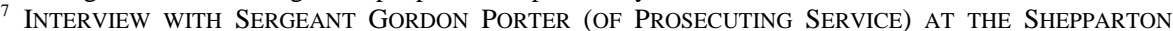
MAGisTRATE's COURT (Jul. 19, 2004).

${ }^{8}$ Dr Roberta Sykes, Self-determination: Implications for Criminal Justice Policy Makers, in JUSTICE PRograms For Aboriginal AND OTHER Indigenous Communities 23 (Kayleen M Hazelhurst ed., 1985)

${ }^{9}$ Id. at 24. 
people by the legal system. The paper will then assess the aims of the Division which resulted from the development process.

Considering that the Division is intended to be a response to the subjection, alienation and exclusion of Aboriginal people ${ }^{10}$ which has traditionally been perpetrated by the justice system, the assessment of the development process, which has the potential to provide some remedy to this legacy, is extremely important in assessing the Division. It involves asking questions such as how were the aims formulated? Who were they formulated for? Have the prescribed aims avoided the danger of paternalism that has marked previous attempts to give control over community problems back to the Aboriginal community? ${ }^{11}$ Is the Division an example of what Deborah Bird Rose refers to as "colonising practices... still deeply embedded within decolonising institutions"? ${ }^{12}$ Can or should the aims of the Division be more culturally relative? At a seminar held in Shepparton to discuss the progress of the Koori Court Division two years into its operation, ${ }^{13}$ rhetoric about "ownership” of the Division by the Koori community was prevalent. Largely used by nonAboriginal people involved in the Division, it was used as a term to show that the Division is a Koori community based initiative and that the Division is a place where Offenders supposedly feel comfortable. The domination of its use by nonAboriginal people is clearly problematic and is indicative of some of the shortfalls of the Division and its development process.

Part 4 is concerned with a limited assessment (limited by the amount of time spent observing the Division and the fact that I was not able to conduct interviews with Offenders who had been through the Koori Court Division process) of whether the Division is meeting its own aims. Part 4 also deals with other issues which have arisen in the sittings of the Division which were not foreseen or considered by the development process. The first step will be to ask, is it possible to see evidence of an attempt to meet the aims the Division has set out to achieve in the way that was intended? This will include, for example, questions of how Magistrates are coping with the non traditional procedure of the Division, how Offenders come to be at the Koori Court Division and how participants are responding to the process. This analysis will draw on my observations of the Court sitting and interviews with people involved with the Division.

I attended the Shepparton and Broadmeadows Koori Courts on six occasions over the period 22 July 2003 to 23 July 2004 and interviewed the Aboriginal Justice

\footnotetext{
${ }^{10}$ See e.g., The Royal COMmission into AbORIGINAL DEATHS In CUSTODY, The NATIONAL REPORT OF THE ROYAL COMMISSION INTO ABORIGINAL DEATHS IN CUSTODY, available at <http://www.austlii.com> (last visited Jul. 4, 2005) Volume 2, Chapter 10; LARISSA BEHRENDT, Aboriginal Dispute RESOlution (1995); Ross Gordon GreEN, Justice in Aboriginal Communities (1998); Larissa Behrendt, Eualeyai: The Blood that Runs Through my Veins, in A WILL TO SuRvive- Indigenous EsSAys on the Politics of Culture, LANGuAge AND IDENTITy 33 (Stephen Greymorning ed., 2004); IVORY SCALES: BLACK AUSTRALIA AND THE LAW 30-81 (Kayleen M. Hazelhurst ed., 1987); DUNCAN GRAHAM, DYING INSIDE 5-32 (1989).

${ }^{11}$ Hazelhurst, id. at 230.

${ }^{12}$ Deborah Bird Rose, Land Rights and Deep Colonising: the erasure of women, 3 ABORIGINAL L.B. 85, 6 (1996).

${ }^{13}$ Two Years On-How Goes The Koori Court, Seminar Conducted at Latrobe University SHEPPARTON CAMPUS (Jul. 8, 2004).
} 
Officers at Shepparton and Broadmeadows (Daniel Briggs and Terrie Stewart respectively), Sergeant Gordon Porter, the Police Prosecutor at Shepparton, Sandra Roberts, a Corrections Officer at Shepparton, Daniel Atkinson, the Client Services Manager at the Shepparton branch of the Victorian Aboriginal Legal Service and Magistrate John Murphy, who sits regularly on the Shepparton Koori Court. The somewhat limited scope of these observations and particularly the interviews is obvious in that I was not able to interview any Offenders who have been through the Koori Court Division process. The number of occasions that I observed the Court sitting is also limited. Therefore, these sources are not adequate to definitively answer the questions outlined earlier and can only be used as an indicator of the Koori Court Division's success or lack thereof in fulfilling its aims. The lack of definitive analysis about the practice of the Division and whether it is effective or not is balanced by the analysis of the potential of the Division, which is the focus of Part 3.

Though I have certainly tried to use court observations along with interviews with Court personnel and participants, these sources are, as discussed above, limited. Their domination by non-Aboriginal rhetoric (most of the Court participants I was able to interview do not belong to the Koori community) means that were they to be relied upon too heavily in this paper, the problem of the power differential between the Aboriginal and non-Aboriginal community, which is one of the Division's biggest challenges, would not be addressed at all. A more useful perspective is to look at these sources as a possible example of a Foucauldian power/knowledge nexus, ${ }^{14}$ in particular, that knowledge of what is "Aboriginal" and what is "Aboriginal" in the sense of attaining justice is potentially being used and dominated by the stronger power (the criminal justice system and its mechanisms of reform), therefore maintaining that power. Similarly, a perspective drawn from Orientalism ${ }^{15}$ is useful considering the tenor of the non-Aboriginal rhetoric about the Division. Most of the rhetoric is extremely positive about the incorporation and recognition of Aboriginal culture and the potential for the Division to be an inclusive and non-alienating experience because of this recognition. Despite this, such rhetoric and the aims and practices of the Division themselves must be examined with the danger in mind that "implicit within the very dynamic of "recognition", however, is the concept that one legal system (the Anglo-Australian legal system) exercises the power to select, represent and order whichever aspects of the other legal system it chooses". ${ }^{16}$ The combination of the use of these perspectives focuses the assessment on where power resides in the development and operation of the Division and examining the power structures of the Division in their entirety, in an ascending analysis. ${ }^{17}$ This can also be translated more simply into the question of whether the Division is merely an example of law reform that "only seeks to make

\footnotetext{
${ }^{14}$ ALAN HUNT AND GARY WICKHAM, FOUCAULT AND LAW 12 (1988).

${ }^{15}$ See generally, EdWARD SAID, ORIENTALISM (1978); BILl ASHCROFT, ON POST-COLONIAL Futures (2001).

${ }^{16}$ Ben Golder, Law, History, Colonialism: An Orientalist Reading of Australian Native Title Law, 9 DEAKIN L.REV. 41 (2004).

${ }^{17}$ HuNT \& WICKHAM, supra note 14 , at 19.
} 
the dominant legal system more acceptable” ${ }^{18}$ rather than to effect substantial and meaningful change by empowering the Koori community.

\section{What IS THE KOORI COURT Division?}

The legislative definition of the Koori Court Division is laid out by the Koori Court Act. ${ }^{19}$ The Act states that the Division should be established with "the objective of ensuring greater participation of the Aboriginal community in the sentencing process of the Magistrates' Court through the role to be played in that process by the Aboriginal Elder or respected person and others." 20 This is one of the few truly prescriptive sections of the Act. The rest of the Act deals mainly with granting authority to the Magistracy to develop the Court. This is with the exception of s 4D (4) and (5) which state respectively that:

The Koori Court Division must exercise its jurisdiction with as little formality and technicality, and with as much expedition, as the requirements of this Act and the Sentencing Act 1991 and the proper consideration of the matters before the Court permit.

And that:

The Koori Court Division must take steps to ensure that, so far as practicable, any proceeding before it is conducted in a way which it considers will make it comprehensible to
(a) the defendant; and
(b) a family member of the defendant; and
(c) any member of the Aboriginal community who is

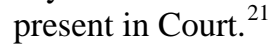

How the Court is to take these "steps" or "exercise its discretion" is up to the Court itself.

S 4D (6) says that "the Koori Court Division may regulate its own procedure". ${ }^{22}$ Potentially, this provision is a positive feature which could enable the Division to be developed in a responsive and innovative manner. However, the potential fluidity of procedure can also raise the issue that a move away from formal legal processes threatens the impartiality of outcomes, ${ }^{23}$ the right to be heard and a fair

\footnotetext{
${ }^{18}$ BEHRENDT, supra note 10 , at 49.

${ }^{19}$ Magistrates' Court (Koori Court) Act, 2002 (Vic).

${ }^{20}$ Magistrates' Court (Koori Court) Act, 2002 (Vic).

${ }^{21}$ Magistrates' Court (Koori Court) Act, 2002, s 4D (4) and (5) (Vic).

${ }^{22}$ Magistrates' Court (Koori Court) Act, 2002 (Vic).

${ }^{23}$ CATHERINE EDITH Bell, InTERCUltural Dispute Resolution in ABORIGINAL ConTEXTs 4 (2004).
} 
hearing generally. Therefore, it is possible that the potential sacrifice of Indigenous rights in court (perhaps leading to an even greater power differential between Koori people and the criminal justice system than what already exists) is not worthwhile in terms of what may be gained by the modified process. One area where this danger does seem to manifest is in the role of the Offender's solicitor, which is discussed in more detail later on in this paper. Generally, based on my observations of the Koori Court Division, the phrase "regulate its own procedure" has not been used in a way which threatens natural justice. At a most basic level, the fluidity of procedure arising from this provision allows for the right to be heard, a key element of natural justice, to be strengthened. As to fluidity of procedure having the effect of lessening Koori people's power in court even further, ostensibly, this does not appear to be the case, with Koori people generally playing a key role in the court process. This is to be distinguished from power differential issues at the development stage of the Court and in a more general and systemic sense, which are exemplified by the simple fact that ultimate power still resides with the Magistrate and that the Koori Court Division itself was still developed very much within the confines of a Department of Justice reform process. ${ }^{24}$ For the potential of s 4D (6) to be used to create a truly responsive Koori Court Division, the power that it gives to regulate procedure needed to be vested in the Koori community. This is discussed more specifically in Part 3.

The other major legislative provisions are that the Division is limited by the Act to deal only with pleas of guilty (effectively rendering it a sentencing court), not to deal with sexual offences and not to deal with cases which involve a breach of an intervention order made under s 22 of the Crimes (Family Violence) Act 1987 (Vic).

The physical formation of the Koori Court Division is unlike that of a normal Magistrates' Court. ${ }^{25}$ The bar table is an oval shape, is in the middle of the room and is not elevated. This is significant for the symbolic value of having everyone sit at the same level. It is also a response to the intimidation commonly felt by Aboriginal people at court, which has been linked to the physical structure of the court, $^{26}$ the adversarial nature of court proceedings ${ }^{27}$ and the legalistic language used in court, ${ }^{28}$ as well as larger issues such as the natural opposition felt when attending a court which is an instrument of a system that has robbed Aboriginal families of their children ${ }^{29}$ and subjected Aboriginal people to human rights depri-

\footnotetext{
${ }^{24}$ See e.g., Second Reading Speech, Magistrates’ Court (Koori Court) Act, 2002 (Vic), in which Rob Hulls makes many references to concepts such as "significant negotiated initiatives”, "partnership” and "developing standards that are owned by the Koori community" but never discusses explicitly the issue of who has the power in this process, indicating that it still resides with the Government. $C f$, Sykes, supra note 8, at 27, where Sykes argues that, in regard to justice programs for Aboriginal people, "anything other than community initiative and control falls into the area of outside imposition-no matter how well-meaning”.

${ }^{25}$ Personal OBSERVATION OF THE BROAdmeAdows AND SHEPPARTON KOORI COURTS ON VARIOUS DATES BETWEEN JUL. 22, 2003 AND JUL. 23, 2004.

${ }^{26}$ HAZELHURST, supra note 10 , at 172.

${ }^{27}$ See BEHRENDT, supra note 10 , at 49.

${ }^{28}$ HAZELHURST, supra note 10 , at 172.

${ }^{29}$ Human Rights AND EQUAL Opportunity COMmission, BRinging THEM Home, available at <http://www.austlii.edu.au/au/special/rsjproject/rsjlibrary/hreoc/stolen> (last visited Jun. 28, 2005)
} 
vations for so long. ${ }^{30}$ Around the oval table sit the two Elders or Respected People and alongside the Elders sits the Magistrate. Also at the table are the Aboriginal Justice Officer (AJO), a Correctional Services representative, the Prosecutor, the Offender's Solicitor, the Offender and a member of the Offender's family or another person who is in attendance to support the Offender. The main purpose of having all these people in Court is to encourage the Offender and members of the Koori community to have a voice, to hopefully not feel marginalised or alienated by the process and to give the Offender's criminality a context which helps the Division carry out its unique approach to sentencing.

One drawback of this procedure is that the role of the Offender's solicitor tends to be marginalised. ${ }^{31}$ The Division seems to operate on the premise that because of the therapeutic approach taken to sentencing, there is less need for the Offender's solicitor to advocate for the Offender. This is not valid considering that despite its modified approach to sentencing, the Division is still very much an instrument of the legal system and the Offender is still receiving a sentence which could leave them with a criminal record with lasting effect. The weakened role of the solicitor in the Koori Court Division means considerations such as this are not given enough weight and the Offender can potentially be disadvantaged.

The procedure varies across the different locations that the Division sits at and from Magistrate to Magistrate. The nature of the Division is that there is flexibility in its process but it is generally in the following sequence. ${ }^{32}$ The case is called by the Clerk of Courts although the Magistrate is usually already at the table. Irrespective of whether he/she is or not, the Court is not asked to rise. This lack of formality is an effort to reduce the potential for intimidation. The Magistrate acknowledges and pays respect to the traditional owners of the land that the Division is sitting on and introduces all the parties present at the table. The Offender's solicitor announces their appearance and indicates that they act for the Offender and that their client is pleading guilty. The police prosecutor reads the charges and provides a summary (there is an imperative for the prosecutor to do this in simplified, non-legalistic language ${ }^{33}$ ), prior convictions are covered and then the Offender's solicitor gives an outline of the Offender's situation.

Proceedings are interrupted if someone needs more information or has something to say; this is done freely without permission or formality. The AJO often speaks about their knowledge of the Offender or enquiries they have made on behalf of or about the Offender. The AJO may ask some of the other Court attendees, especially service providers such as the Community Health Worker if they have anything they want to say to the Court. Towards the end of the hearing, the family or support person will usually be invited to speak and then the Magistrate will ask the Elders if they have anything to say to the Offender. Generally the Offender is asked if they have anything to say to the Court at the end of the process. The Magistrate then

\footnotetext{
${ }^{30}$ See Royal Commission into Aboriginal Deaths in Custody, supra note 10, Volume 2, Chapter 10 , and BEHRENDT, supra note 10 , at 41.

${ }^{31}$ PERSONAL OBSERVATIONS, supra note 25.

${ }^{32} I d$.

${ }^{33}$ Magistrates' Court (Koori Court) Act, 2002, s 4D (5) (Vic).
} 
consults with the Elder/s at the bar table and sentence is given in an open and audible fashion. $^{34}$

\section{DeVelopment: What aRe the Division's Aims AND How} WERE THEY FORMULATED?

This section of the paper addresses the development of the aims of the Koori Court Division with the perspective that for them to contribute positively to the Court, they needed to be responsive to the Koori community and inclusive of that community in their formulation and their substance. In addition, they needed to address the power imbalance between the Koori community and the criminal justice system. The establishment of the Division was guided by a set of essentially hierarchical aims. The overriding aim is to address Aboriginal overrepresentation in the criminal justice system. ${ }^{35}$ This is clearly necessary considering that Aboriginal people in Victoria are 13 times more likely to be imprisoned than non-Aboriginal people. ${ }^{36}$ This figure has continued to rise despite the work of the RCIADIC in publicising the overrepresentation of Aboriginal people and calling for an effective response to it. $^{37}$

In the aims of the court it is possible to see a mechanism that is striving for a Koori community based outcome, which is logically the most effective way for the Division to be responsive to the Koori community. This is strongly supported as the best response to the problems that Aboriginal people face in their experiences with the criminal justice system and the broader social and economic disadvantages which stem from or are related to these problems. ${ }^{38}$ Aside from the official statements about the aims of the Court, there has been independent rhetoric which makes the claim that when the Division was being developed the Koori community "took over". 39

However, in assessing the aims of the Division in general, it is important to examine exactly who it was that "took over" their development and who it is that is saying that the Koori community "took over", in order to asses whether this comment really indicates a measure of community involvement, consultation and control in the development of the Division's aims. Shepparton has served as the model for all three Courts and it was there that a great deal of the development process took place. ${ }^{40}$ A Koori Court Division Reference Group was formed to facilitate this process. The members of the group were Dr Kate Auty-the regional coordinating

\footnotetext{
34 Dr Kate Auty and DANiel Briggs, KoOri Court Victoria-Magistrates' Court (KoOrI COURT) ACT 2002, paper presented at the Seventh Colloquium of the Judicial Conference Australia (May 30, 2003).

${ }^{35}$ Dr Mark Harris, Koori Courts in Victoria; An Interim Evaluation of the Shepparton and Broadmedows Koori Courts (unpublished, on file with the author).

${ }^{36}$ VICTORIAN ABORIGINAL JUSTICE FORUM, supra note 3, at 15

${ }^{37}$ ROYAl COMMISSION INTO ABORIGINAL DEATHS IN CUSTODY, supra note 10.

${ }^{38}$ See KaYleEn HaZelHuRst, Legal PluRAlism AND THE COLONIAL LEGACY 159-217 (1995)

${ }^{39}$ KATE Auty, TWO YEARS ON-HOW GOES THE KOORI COURT, supra note 13; INTERVIEW WITH DANIEL

Briggs, SHEPPARTON MAGISTRATES’ COURT (Jul. 19, 2004).

${ }^{40}$ INTERVIEW WITH GORDON PORTER, supra note 7.
} 
Magistrate at the time, Rose Coombs-a Yorta Yorta woman attached to the Department of Justice, representatives from the Sheriff's Office and the Police, a Corrections Officer, two representatives from the Regional Aboriginal Justice Advisory Committee (RAJAC), the Court Registrar, two Victorian Aboriginal Legal Service representatives, a Legal Aid solicitor, a representative from local Aboriginal cooperative (Rumbalara) and a Juvenile Justice worker. ${ }^{41}$ It was asserted, though problematically not by the Koori community themselves, that the Koori community were vocal and participated strongly. ${ }^{42}$ Lending more weight to this assertion of strong participation was media coverage of the Division's inception, with several articles including comment from the local RAJAC, ${ }^{43}$ indicating their involvement.

It was also said that "the sophistication Aboriginal people have developed over the years in their dealing with government agencies...was exploited to good effect by Aboriginal people...embracing the initiative". ${ }^{44}$ This comment is also problematic as it is not made by a member of the Aboriginal community. In addition, its use of language can be read as suggestive of imposition. One does not usually embrace one's own initiative but someone else's, which casts doubt on assertions that the Division was truly a community based initiative. However, the word "embracing" is juxtaposed with "exploited", suggesting that some power did reside with the Koori community in the process.

It is questionable however, why Elders from the community were not included in the Reference Group, which would have increased the potential of the Division to be truly culturally relevant and to have more effectively addressed the fundamental power imbalance between the criminal justice system and the Aboriginal community by more fully incorporating leaders of that community. The Elders did play some role in the development process, in that it was asserted that that they were extensively involved in the training process they underwent, ${ }^{45}$ which apparently became more of a forum for them to express their views about the Division rather than a didactic experience. ${ }^{46}$

It is also important to consider who the Elders were that were involved (albeit in a somewhat limited capacity) in this process and who continues to be involved. There is a danger that only Koori people with access to the representative structures for their community would play a role in shaping the Division. This means that in addition to the development process continuing the power imbalance between the Koori community and the non-Aboriginal community, those Koori people who have been particularly affected by the criminal justice system, were not heard either. Indeed, commentary of the development process has indicated that this was

\footnotetext{
${ }^{41}$ Attendance Page from Minutes of Meeting held 22 July 2002 (provided by Gordon Porter, on file with the author).

${ }^{42}$ FAX/Letter from Sergeant Gordon Porter to Inspector Wigg, KoOri Court Pilot Project (24 Dec. 2002, on file with author).

${ }^{43}$ See e.g., New Koori Court Opens, AAP NEwSFEED, Sept. 6, 2003.

${ }^{44}$ AUTY \& BRIGGS, supra note 34.

${ }^{45}$ Although, it can be argued that the fact that Elders were required to undertake a training course at all is problematic. It is very possible that this is a classic example of the dominant legal system selecting and shaping the knowledge of the other, therefore perpetuating its dominance.

${ }^{46}$ FAX/LETTER FROM GORDON PORTER TO INSPECTOR WIGG, supra note 42.
} 
the case and that it was "Aboriginal agencies operating within the law" and "Aboriginal co-operatives and service providers" who "opened the channels of communication". ${ }^{47}$ It could then be argued that people who have access to or are involved in those structures would be the least likely to be before the Division as Offenders, thus perhaps reducing its relevance. However, analysis of who within the Koori community participated in the process masks the bigger issue of who controlled and funded the process overall.

There is no evidence of funding being offered to Koori organisations to independently develop a framework for the Division. This, in combination with other aspects such as the fact that it was seen as necessary to train the Elders (thus downgrading the value of their knowledge and suggesting that their knowledge had to undergo some form of transformation to suitably fit within the workings of the criminal justice system) and the large amount of commentary surrounding the court by nonAboriginal people (suggesting that they dominated the commentary surrounding the Division) can be seen as an indication that power was not vested in the Aboriginal community to develop the Division and that it is therefore reinforcing the "colonial relationship of superiority and inferiority". ${ }^{48}$

In regard to the above discussion of the lack of input from Koori offenders, this is counteracted to some extent by the life experiences of the Elders who sit on the Court. At least two speak openly in Court about their own experiences in the criminal justice system. ${ }^{49}$ The fact that the Elders were able to have an impact on the formation of the Division by expressing their views during their training to sit on the Court (which also apparently had a positive impact upon police relations with Koori people ${ }^{50}$ ) and that those Elders were people who had been through some of the issues that Offenders in the Division would be facing helps to refute some of the danger that the Division would not be relevant to Offenders. The potential for this to be extended to the practice of the Division is unfortunately countered by the fact that the Magistrate has the power to make the ultimate determination on sentence, despite what the Elders may think is appropriate. ${ }^{51}$

One of the primary aims of the Koori Court Division ${ }^{52}$ is to reduce the overrepresentation of Koori people in the legal system or more simply, diversion. ${ }^{53}$ This is in keeping with the RCIADIC's recommendation number $92,{ }^{54}$ which states that imprisonment of Aboriginal people should be used only as a sanction of last resort. This particular aim of the Division is clearly valid. Its validity is supported not only

\footnotetext{
${ }^{47}$ AUTY \& BRIGGS, supra note 34.

${ }^{48}$ Chris Cunneen, Conflict, Politics And Crime: Aboriginal Communities and the Police 8 (2001).

49 Personal observations of the Broadmeadows Koori Court (Jul. 20, 2004) and The SHEPPARTON KOORI COURT (Jul. 9, 2004).

${ }^{50}$ FAX/LETTER FROM GORDON PORTER TO INSPECTOR WIGG, supra note 42.

${ }^{51}$ See, e.g., INTERVIEW WITH TERRIE STEWART, BROADMEADOWS AJO, PhONE INTERVIEW (Jun. 27, 2003) who indicates that on occasion the Elders advocate a harsher approach and/or sentence for an Offender than the Magistrate thinks is appropriate.

${ }^{52}$ See Harris, supra note 35 and OPERATING MANUAL FOR THE KOORI COURT (provided by Gordon Porter, on file with the author).

${ }^{53}$ Harris, supra note 35.

${ }^{54}$ RoYAl COMMISSION INTO ABORIGINAL DEATHS In CUSTODY, supra note 10.
} 
by the huge significance of the RCIADIC's work (in pointing out the inherent danger of imprisonment for the physical and mental health of Aboriginal people) but can also be seen in the Division's operation. A defendant at the Broadmeadows Koori Court Division with a severe and extensive criminal history appeared in July 2004. ${ }^{55}$ The Court had difficulty formulating a sentence for him and the possibility of a prison term was raised. The AJO offered the opinion that "He does jail easy, jail won't do him any good". This is a strong example of why imprisonment should be a sentence of last resort; sometimes it has no utility, particularly for rehabilitative purposes. This change in attitude towards imprisonment and the benefits of it is also supported by the Magistracy; "people are perceptibly more answerable in a Koori Court...they have to explain themselves, they have senior members of the community saying, "we don't approve of this conduct"... jailing is the easiest thing one can do...it's more difficult to find some other penalties and see if they can help the community as well as the defendant”. ${ }^{56}$ The problem is whether this aim extends far enough to the root of the problem. If the involvement of the Anglo legal system and its concepts in the lives of Aboriginal people as an act of domination to the detriment of their cultural identity is seen as part of the problem, ${ }^{57}$ then the legal concept of diversion could be simply another to add to the list. Countering this will necessitate a thoughtful application of diversion in the sentencing of Koori offenders and most importantly, for the Koori community to be involved in its application.

The diversion aim of the Division is validated by the response from Offenders. Many participants in the Court have highlighted that to deal with their issues, in terms of seeking treatment and getting their lives back on track, is true punishment because it is more difficult than jail will ever be. ${ }^{58}$ Similarly, many speak of the role the Elders play in "shaming" the Offender as being much more effective than a prison term. ${ }^{59}$ This is reflected in comments by Elders; "when you look at them in Court they know and they listen" 60 and Offenders; "one of the Elders was disgusted by my record and she had always thought highly of me...she didn't think I was this bad. It made me think" ${ }^{61}$ The effectiveness of a similar concept of "shaming" as that used by Aboriginal Elders has received support from criminologists such as John Braithwaite. ${ }^{62}$ He argues that shaming is an effective way to control crime but that it must be careful to avoid the danger of stigmatisation of Offenders in doing so. This he argues can be avoided by shaming being accompanied by gestures of reacceptance into the community, which is better accomplished where a community

\footnotetext{
${ }^{55}$ Personal observation of Broadmeadows Koori Court (Jul 20, 2004).

${ }^{56}$ Magistrate Kumar quoted in Shelly Hodgson, Koori Court Finds Favour; Friendly Fire and a Cultural Context, Sunday HeRALD Sun, May 4, 2004.

${ }^{57}$ See Royal COMmission InTO ABORIGINAl DEATHS IN CUSTODY, supra note 10, Volume 2, Chapter 10.

${ }^{58}$ Anonymous Offender, The Law Report, Feb. 3, 2004, Radio National, Shepparton's Koori Court, available at <www.abc.net.au/rn/talks/8.30/lawrpt/stories/s1035995.htm> (last visited Sept. 20, 2004), full quote at page 23 of this paper.

${ }^{59}$ AUTY \& BRIGGS, supra note 34

${ }^{60}$ Aunty Norma Langford (Broadmeadows Elder) quoted in Hodgson, supra note 56.

${ }^{61}$ Adam Morton, Elders Key in Nunga Courtroom: A pioneering Court system that takes a different approach to Aboriginal justice is finding success across the country, TOWNSVILLE BULLETIN, Jul. 12, 2003.

${ }^{62}$ JOHN BRAITHWAITE, CRIME SHAME AND REINTEGRATION (1989).
} 
has a higher level of interdependency and highly developed communitarianism. Without stereotyping the nature of Aboriginal communities, it is arguable that a Koori community has the necessary characteristics for reintegrative shaming to be effective. ${ }^{63}$ Another key aspect of Braithwaite's ideas on shaming which indicates its effectiveness is that it is better to be shamed by one's community than by the state. $^{64}$

However, the issue of Aboriginal overrepresentation in the prison system is not as simple as saying that diversion ${ }^{65}$ is the answer. Diversion has the effect of reducing the statistics of overrepresentation, but perhaps not the causes of it. On its own, and without sufficient commitment, the aim to reduce overrepresentation can be read as an aim to make the treatment of Aboriginal people by the justice system look better rather than to truly make it better. ${ }^{66}$ To combat this, the aim of diversion must be supported by a raft of other aims which seek to address the causes of overrepresentation. There is indication that the Division was created with supporting aims in mind, reflected in the Second Reading speech for the Magistrate's Court (Koori Court) Bill (2002) in which Rob Hulls said that "We do not pretend that the Koori Court is the only answer to address the alarming number of Aboriginal people represented within our justice system”. ${ }^{67}$ Furthermore, the Koori Court Division has its origins in the VAJA which purports to address disadvantage and various problems of a social nature, ${ }^{68}$ providing support for Offenders who are diverted and the diversionary approach in general.

Another of the Division's major aims is the incorporation of Koori people in the legal process. This aim is interesting for the different ways in which it is expressed and understood, giving it vastly different meanings. These different meanings can essentially be split up into "incorporation" by attempting to get Koori people to work better within the system as it is (straight incorporation) and "incorporation” by adapting the system to better suit the needs of Koori people, so that they can feel more comfortable within it and so that its "easier ...to come along and have your say in Court" ${ }^{69}$ (adaptive incorporation). On the face of it, the Koori Court Division appears to be an example of the latter. However, a deeper analysis of the attitudes of those within the Division and some of the language used in the development process reveals that the adaptive approach is not necessarily what everyone understands the Division to be. These differences are essentially driven by differences in

\footnotetext{
${ }^{63} \mathrm{Id}$. at $85-87$ and see also, BEHRENDT, supra note 10 , at 49 and 75 , where she outlines some key characteristics of Aboriginal Dispute Resolution that are similar to the pre-conditions that Braithwaite argues are necessary.

${ }^{64}$ BRAITHWAITE, supra note 62 at 97.

${ }^{65}$ The use of the term 'diversion' here means the broader definition of diversion in that the Offender is officially diverted from a sentence or a particular type of sentence, encompassing sentencing schemes which begin and end in the Koori Court Division such as supervised Community Based Orders and the basic imperative to divert Offenders away from prison sentences.

${ }^{66}$ See ROYAl COMmission INTO ABORIGINAL DEATHS IN CUSTODY, supra note 10, Improving the Indicator not the Quality of Life, Volume 2, Chapter 11.

${ }^{67}$ Second Reading Speech, Magistrate’s Court (Koori Court) Act, 2002 (Vic).

${ }^{68}$ DEPARTMENT OF JUSTICE, supra note 1.

${ }^{69}$ DEPARTMENT OF JustiCE, A DEFENDANT’s Guide to THE KOORI COURT (Court pamphlet, undated, on file with the author).
} 
the attitudes of the people involved which in turn illustrates a difficulty in addressing the power differential between the Koori community and the criminal justice system. Addressing the power differential requires a commitment to changing the structure of power in the Division. The progression from seeing straight incorporation as all that can be achieved to seeing that adaptive incorporation can be achieved is a necessary step towards that commitment.

Elucidation of the aims of the Division into terms such as "promote better awareness in the Aboriginal community of their civil, legal and political rights"70 indicates that straight incorporation is occurring. The "promotion of better awareness" suggests educating Koori people as to what the system is, as it is. Also, comments by personnel such as "its still a court of law", ${ }^{71}$ made in the context of not changing court process excessively, display the straight incorporation approach.

However, there is some commentary supporting the adaptive incorporation approach. The adaptive incorporation approach, understanding and attitude is exemplified in comments by Magistrate Kate Auty, who played a key role in the development of the Division. She asserts that the Division is an example of "culture... intruding into otherwise formulaic legal spheres"72 and she utilizes Delgado's critical race theory to advocate "recognizing their [Aboriginal people's] place in the narrative" ${ }^{73}$ In addition, much of the official or quasi-official literature on the Koori Court Division makes reference to "cultural appropriateness" and "cultural relevance". ${ }^{74}$ The processes associated with these terms could not be accomplished without some change as opposed to just straight incorporation. Unfortunately, adaptive incorporation still stops short of addressing the issue of power. Auty asserts that Aboriginal people's place is recognised in the narrative but because the issue of power imbalance is not explicitly addressed, that place is still subjective.

In terms of its response to Aboriginal justice issues, the aim of incorporation into the legal system, without the distinction discussed above, can still be a valid aim. Evidence shows that Aboriginal people face various problems in the Court process. ${ }^{75}$ When Koori Court Division personnel were asked what they thought was the biggest problem Koori people faced when they came into contact with the justice system, the most common answer was "lack of understanding". ${ }^{76}$ Incorporation is clearly an effective tool to combat this, no matter how it is expressed. Incorporation

\footnotetext{
${ }^{70}$ Department of Justice, The Koori Court (PowerPoint document, provided by Sergeant Gordon Porter, on file with the author).

${ }^{71}$ INTERVIEW WITH TERRIE STEWART, supra note 51.

${ }^{72}$ AUTY \& BRIGGS, supra note 34.

${ }^{73} \mathrm{Id}$.

${ }^{74}$ See e.g., OPERATING MANUAL FOR THE KOORI COURT, supra note 52 and MAGISTRATES' COURT OF VICTORIA, WHAT IS THE KOORI COURT?, available at <http://www.magistratescourt.vic.gov.au> (last visited Aug. 11, 2004).

${ }^{75}$ See e.g., Andrew Ligertwood, Aborigines in the Criminal Courts, in ABORIGINES AND THE LAW: ESSAYS IN MEMORY OF ELIZABETH EGGLESTON 191 (Peter Hanks ed., 1984); Hazelhurst, supra note 10, at 172; BEHRENDT, supra note 10, at 49.

${ }^{76}$ INTERVIEW WITH DANIEL BRIGGS, supra note 38, INTERVIEW WITH SANDRA ROBERTS, CORRECTIONS OFFICER, PHONE INTERVIEW (Jul. 28, 2004), INTERVIEW WITH MAGISTRATE JOHN MurPhy, SHEPPARTON MAGISTRATES' COURT (Jul. 19, 2004), INTERVIEW WITH TERRIE STEWART, supra note 51.
} 
will arguably also have a positive effect upon perceptions within the Aboriginal community that when an Aboriginal person breaks the law they are breaking the "mainstream law"," although this perception is arguably correct. Considerable caution must be exercised in this area so that comments about how incorporation can rectify this perception or reduce its negativity do not become absolutist and morph into the narrow minded dictum that our system is not pluralist and cannot incorporate anything that conflicts with its tradition. ${ }^{78}$ Arguments for incorporation could be used for this purpose and become arguments for assimilation in disguise. This highlights how the aims of the Koori Court Division, to be effective in terms of incorporation, need to be read with an appropriate attitude and in conjunction with the Division's other aims. The attitudinal problem is difficult to address, though education is a potential remedy for it, which has been included in the Division's operations to some extent. However, Dr Mark Harris' interim report makes the recommendation that there needs to be more focus on community awareness and cultural awareness training, which are linked to education. ${ }^{79}$

Offshoots of the general aim of incorporation are to "make it easier...to come along and have your say in Court" ${ }^{\prime 0}$ and reducing the alienation that Aboriginal people commonly feel when they come into contact with the criminal justice system. Initiatives which help with these off-shoots of the basic aim are using plain language and utilizing the Elder's "cultural knowledge" and status so that what is said to the Offender is not from a "distant legal authority, which may make Offenders feel afraid and bad about themselves". ${ }^{81}$ This is supplemented by the attendance of family and other supports.

The strengthening of the Koori community, its involvement in the criminal justice system and to some extent community control are important elements of the Koori Court Division also. The VAJA, which was the foundation for the Division, explicitly states that

A core principle of the Agreement is maximising participation of the Koori community in the design, development, delivery and implementation of all justice policies and programs that impact on the Koori community. Regardless of whether the programs are community or government based, there must be maximum participation by the Koori community if the initiative is to be successful. ${ }^{82}$

\footnotetext{
${ }^{77}$ Rob Hulls, Koori Court is Crucial, HeRALD Sun (Mar. 14, 2003).

${ }^{78}$ JoHn LOWNDEs, Northern TerRitory Magistrate, SPEECH GIVEN AS PART OF A LeCtURE AT UNIVERSITY OF MELBOURNE (Mar. 18, 2004).

${ }^{79}$ Harris, supra note 35, Recommendations 20 and 4.

${ }^{80}$ DEPARTMENT OF JUSTICE, supra note 69.

81 Elena Marchetti \& KathleEN DALy, Indigenous Courts and Justice Practices iN Australia (2004).

${ }^{82}$ Department of Justice, What is the role of the koori community in implementing the agreement?, available at <http://www.justice.vic.gov.au> (last visited Aug. 16, 2004).
} 
Similarly, the Koori Court Division itself is set up with this aim in mind, reflected in statements that say that the Division aims for "greater participation of the Aboriginal community in the sentencing process" ${ }^{83}$

The importance of community control over issues and problems in Indigenous communities be they justice related or not has been reiterated time and time again, in many different ways. It is argued that the devastating loss of spiritual and cultural identity is a root cause of many problems within Indigenous communities ${ }^{84}$ and that this loss is strongly linked to the dissolution of community. ${ }^{85}$ The aim of community building has the potential to counteract this problem in many ways, chiefly by enabling the community to be strong enough to take control of justice initiatives. By having Elders sitting in the Koori Court Division, the value of Aboriginal culture and therefore community is recognised. Similarly, by making the younger generation accountable to their Elders, the traditional social structure of the Aboriginal community is recognised and hopefully revived. ${ }^{86}$ It is also argued that Aboriginal communities and Aboriginal law have a unique way of responding to dominating influences and that

Hopeful signs emerge from recent community based justice programs whereby Indigenous law functions in its own right, utilising mechanisms derived from and recognised by the Australian legal system without being dominated or controlled. ${ }^{87}$

This comment represents not only the positive aspects of community based justice approaches but is also linked to the preceding comments about the importance of the regeneration of cultural identity. Community control and involvement is also an extremely valid aim for the Court when viewed in light of comments such as "Fieldwork research points to the roots of Aboriginal "crime" lying not in the criminal justice system per se, but in the legacy of dispossession and colonization" ${ }^{88}$ In part, community participation in response to such a comment has the potential to be a response to the disempowerment and years of mistreatment by the system. At a most basic level, it can function as an attempt to reverse the traditional view of the legal system which labeled the Aboriginal community as the "other" and was part of the general detrimental approach of colonisation. ${ }^{89}$

Community based approaches are further validated by Rebecca Tomkin, who asserts that "in the Aboriginal community the focus is holistic and specific, events cannot be separated from the whole of culture and community" ${ }^{90}$ Through this

\footnotetext{
${ }^{83}$ OPERATING MANUAL FOR THE KOORI COURT, supra note 52.

${ }^{84}$ Teena Balgi, Moving beyond the Royal Commission, 5 Indigenous L.B. 8, 12 (2001).

${ }^{85}$ ARATJARA: ABORIGINAL CUlTURE AND Literature In AUSTRALIA 47 (Dieter Riemenshchneider and Geoffrey V Davis eds., 1997)

${ }^{86} I d$.

${ }^{87}$ INDIGENOUS LEGAL ISSUES: COMMENTARY AND MATERIALS 219 (Heather McRae, ed., 2003)

${ }^{88}$ Hazelhurst, supra note 10.

${ }^{89}$ AUTY \& BRIGGS, supra note 34.

${ }^{90}$ Rebecca Tomkin, Crime Prevention Strategy for Aboriginal Communities, in ABORIGINAL JustiCE ISSUES: PROCEEDINGS OF A CONFERENCE HELD 23-25 JUNE 1992 (Sandra McKillop ed., 1993).
} 
comment it is evident that a community based/control approach is likely to have more success in terms of quantitative results.

However, there are dangers inherent in utilising community based approaches which the Koori Court Division must be mindful of. One of these is that "although the strength of the community development approach is that people own their own problems and they own their own solutions and it is empowering, the way of involving people must be culturally appropriate and this needs to be negotiated with people rather than assumed". ${ }^{91}$ Larissa Behrendt elaborates this further, making the comment that "if they (the non-Aboriginal community) wish to negotiate with an Aboriginal community, they need to do so within the frameworks that Aboriginal people find acceptable". ${ }^{92}$

Another issue outlined by some commentators regarding community based approaches is that of putting too much pressure on the community in that "it is...unrealistic to assume that all communities have the capability to confront crime". ${ }^{93}$ This danger seems to have been avoided in terms of formulating the aims of the Division. It was certainly foreseen that the Aboriginal community would have some role to play in its operation, but there is no specific requirement that this be the case. ${ }^{94}$ The community has been able to include itself in the process to the level which it desires. However, there have been some glimpses of the danger discussed above, in literature such as the Victoria Police Operation Manual for the Division, ${ }^{95}$ which states that one of its aims, from an "Aboriginal Community Perspective" is to "increase the accountability of the Koori community". ${ }^{66}$ This danger seems to be minimal though and would hopefully be counteracted by the autonomy afforded to the community in deciding how they will be involved.

Though on the whole, the Koori Court Division's aims seem progressive and sensitive, there are some ideas which could be developed further. Perhaps the most important of these is self-determination and the attendant issue of devolution of power to the Koori community. ${ }^{97}$ The lack of consideration of or commitment to these ideas creates a shortfall in the validity of the Koori Court Division and its potential to truly address problems Koori people face in the criminal justice system and in Australian society in general.

It is arguable that the Koori Court Division's aims stop short of promoting any kind of real self-determination, although the rhetoric surrounding the Court certainly

\footnotetext{
${ }^{91}$ Barbara Miller, A Community Development Approach to Crime Prevention in Aboriginal Communities, in ABORIGINAL JustiCE IsSUES: PROCEEDINGS OF A CONFERENCE HELD 23-25 JunE 1992 (Sandra McKillop ed., 1993)

${ }^{92}$ BeHrendT, supra note 10 at 27. Note that Behrendt is talking about land rights but I believe this comment has universal application and is just as relevant to Aboriginal people's negotiations with the criminal justice system.

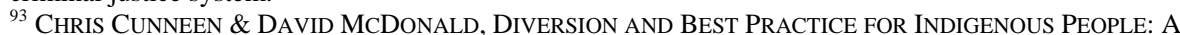
NON-INDIGENOUS VIEW 8 (1999).

${ }^{94}$ Magistrates' Court (Koori Court) Act, 2002 (Vic).

${ }^{95}$ OPERATING MANUAL FOR THE KOORI COURT, supra note 52.

${ }^{96}$ Id. at 39.

${ }^{97}$ RoYAl COMMISSION INTO ABORIGINAL DEATHS IN CUSTODY, supra note 8, Volume 2, Chapter 20.
} 
tries to make it sound like self-determination is being promoted. ${ }^{98}$ Like regeneration of cultural identity and community control, self-determination is often argued to be an essential element in the success of any approach to Indigenous justice issues. ${ }^{99}$ The argument is made that until a commitment is made to selfdetermination, any approaches towards Aboriginal justice are dominating, paternalistic and patronising even if it is in the most imperceptible way. This has led Aboriginal commentators such as Dr Roberta Sykes to conclude that this represents the danger of a continuation of the power imbalance between the non-Aboriginal and Aboriginal community and that "we would be fools to co-operate on such a basis". ${ }^{100}$ Without self-determination as the basic imperative, these negative characteristics cannot be shed.

Self-determination has been defined by the RCIADIC as "significant devolution of decision making power to Aboriginal people over a wide range of issues which would otherwise be determined by non-Aboriginal people". ${ }^{101}$ This definition, in its focus on power, again highlights the biggest issue for the Koori Court Division. In terms of how this "significant devolution" can be effected, the RCIADIC endorses the role of key Aboriginal organisations, asserting that they are accepted by the community as representative and that they are therefore valid negotiators and representatives in establishing self-determination. This in some way validates the approach of the Koori Court Division in terms of self-determination, particularly the role played by the RAJACs. However, the involvement of Aboriginal community organisations alone is clearly not sufficient to fulfil self-determination if in the end, it does not result in a true "devolution of power". Also, as discussed earlier, the involvement of Aboriginal community organisations exclusively could have some limitations for the Koori Court Division specifically.

Another hurdle for the realisation of self-determination is that asserted by Chris Cunneen, who points out that Australian governments often use self-determination largely as an administrative policy rather than recognising it as an inherent right. ${ }^{102}$ This weakens the power of the concept of self-determination ${ }^{103}$ and inhibits its full realisation and the expansion of its definition to mean real power for Aboriginal people by limiting its use to community consultation on projects which will ultimately be funded and decided by the government. The limitations of the development process of the Division such as the absence of formal involvement by the Elders and the fact that the Koori community was not given the chance to inde-

\footnotetext{
${ }^{98}$ See e.g., Rob Hulls, Message Stick (Apr. 22, 2005) available at

$<$ http://www.abc.net.au/message/tv/ms/s1348669.htm>, where the concept of 'ownership' is used and there is discussion of the Koori Court Division as an initiative that is 'borne out of the Koori community'.

${ }_{99}$ See e.g., CUNNEEN \& MCDONALd, supra note 93; HAZELHURST, POPULAR JUSTICE AND COMMUNITY REGENERATION Part 1, 3-103 (1995) and ROYAL COMMISSION INTO ABORIGINAL DEATHS IN CUSTODY, supra note 8 , Volume 2, Chapter 20.

${ }^{100}$ Sykes, supra note 8 , at 24 .

${ }^{101}$ Royal COMmission INTO ABoriginal DeAtHS In Custody, supra note 8, Volume 2, Chapter 20.

${ }^{102}$ CunNEEN, supra note 48, at 242.

${ }^{103}$ See W. Sanders, Towards an Indigenous Order of Government: Rethinking self-determination as Indigenous Affairs policy, available at <http://www.anu.edu.au/caepr/Publications/DP/2002_DP230.pdf> (last visited Jul. 14, 2005).
} 
pendently develop a framework for the Division shows that self-determination in the Division was somewhat limited to being an administrative policy.

Self-determination could possibly be fulfilled by recognition of Aboriginal customary law. ${ }^{104}$ However this is regarded as problematic in Victoria where there is a lack of "traditional living" that would have kept customary law alive, ${ }^{105}$ which in turn leads to the perception that there is no customary law to be recognised. This perception is indicative of the narrow view of Aboriginal culture and ignores the fact that "distinct cultural values exist today in urban Aboriginal communities"106 and highlights that there "seems to be some problem with non-Aboriginal people conceptualising the autonomy of urban Aboriginal communities". ${ }^{107}$ These are problems for the recognition of customary law generally but are particularly relevant for Victoria's Koori Court Division, which (particularly at Broadmeadows) services what would be regarded as a more urbanised Aboriginal community. ${ }^{108}$

Aside from the ramifications this narrow perception can have for the recognition of Aboriginal customary law, it could potentially have had an impact on the development and procedures of the Koori Court Division. The ingrained belief that an urban Aboriginal community is not sufficiently "Aboriginal” could have contributed to the deficiency in devolution of power to that community in the development process and in some features of the Division such as power still ultimately residing with the Magistrate. The view that urban Aboriginal communities are more disparate and therefore less coherent has arguably contributed to the perception that there is not enough of a community to devolve power to. This is reflected in seemingly progressive statements such as that the Division is aiming for "the incorporation of Aboriginal people's knowledge, skills, values, cultural beliefs and practices into the dominant society's processes, practices and norms, of which the legal system is one". The problem with this statement is that it is not accompanied by any explicit statements that give the Aboriginal community sole power to say what those skills, values, practices and norms are. Perhaps if urban Aboriginal communities' "Aboriginality" was not doubted or perceived so narrowly, the system would be more willing to devolve the power to the Koori community to have total control in asserting this knowledge and in finding a place for it in the criminal justice system.

Overall, although there were attempts to include and consult the Koori community in the development of the Koori Court Division, the process stopped short of handing over sufficient power to the Koori community. The problems Aboriginal people face in the criminal justice system clearly have their roots in the subjection of

\footnotetext{
104 See Australian LAW REFORM COMMISSION, THE RECOGNITION OF ABORIGINAL CUSTOMARY LAW (1986). The Commission recognised in its report that considering the question of recognition of Aboriginal customary law was in a sense, putting the cart before the horse because they did not first address selfdetermination.

${ }^{105}$ INTERVIEW WITH TERRIE STEWART, supra note 51.

106 See also, Lin Onus, Language and Lasers and Michael Dodson, The end in the beginning: re(de)finding Aboriginality, in BLACK LINES: CONTEMPORARY CRITICAL WRITING BY INDIGENOUS AUSTRALIANS (Michele Grossman, ed., 2003) for a discussion of the distinction between urban and traditional Aboriginality and its rigidity and invalidity.

${ }^{107}$ BEHRENDT, supra note 10 , at 77.

${ }^{108}$ INTERVIEW WITH TERRIE STEWART, supra note 51.
} 
Aboriginal people generally and the dominance and control over their lives. ${ }^{109}$ The criminal justice system manifested this in a particularly visible way, with practices such as Aboriginal people not being allowed to testify in court, being denied the defence of provocation if a white person was the provocateur and dealing out lenient punishments for the rape and murder of Aboriginal people. ${ }^{110}$ A legacy like this is hard to rectify and involves a need for Aboriginal people to be given real power in the court process and the development of a court that is purportedly for their benefit. A true devolution of power is crucial in addressing the deep mistrust and anger that Aboriginal people justifiably feel towards a system which has perpetrated such atrocities and arguably continues to evidence neo-colonialist practices even today. ${ }^{111}$

\section{Procedural: Is the Division Meeting its OWn Aims And HoW ARE Things GoIng In Practice?}

Not only must the Koori Court Division be developed as a responsive and inclusive mechanism for the Koori Community it must also fulfil this aim in practice. The development of the aims of the Division and the problems with this process will obviously act as a restriction on this and limit the responsiveness and inclusiveness that can be achieved. However, it is still important to examine the Division in practice and not dismiss it out of hand, as despite the critical perspective this paper takes on its development process and its limited address of issues such as power, it remains a progressive approach to Aboriginal justice issues and is certainly a step in the right direction in contrast to the paternalistic and assimilating programs that have gone before it. ${ }^{112}$

An assessment of the procedural and practical aspects of the Division can be split up into two discreet categories; whether the Division is meeting its own aims in practice $^{113}$ and what other structural and procedural issues have arisen in the Division's operation that are not related specifically to the aims of the Division. The first category will rely heavily on qualitative information rather than quantitative as there is insufficient statistical data at present. ${ }^{114}$ The lack of statistical data is not a problem for this analysis considering that although the success of the Division could be indicated by low re-offending rates and few failures to appear, as Richard Edney points out, this is not really in keeping with the purpose or aims of the Divi-

\footnotetext{
${ }^{109}$ See RCIADIC, supra note 8, Volume 2, Chapter 10

${ }^{110} \mathrm{Id}$.

${ }^{111}$ See e.g., Golder, supra note 16.

112 Arie Freiberg, Australian Institute of CRiminology InTERnAtional Conference 2004, CONFERENCE PAPER: INNOVATIONS IN THE COURT SYSTEM and McRae, supra note 87, at 229-230.

${ }^{113}$ To some extent this is addressed independent of the discussion in Part 3 of whether they are valid or not and is more focused on the type of criteria that is outlined in the quote by Richard Edney in the paragraph below. This is because this paper, though critical of the development process, does not view it as disabling the potential of the Division in general. The criteria is also shifted to that outlined by Edney in part so that the essay can continue to an examination of the practice of the court as obviously if it is argued that the development process was fatal to the Division's potential then there would be little point in examining the practice aspect.

${ }^{114}$ Harris, supra note 35.
} 
sion. The Division should be assessed in terms of whether "such a Court has contributed to an enhanced quality of life of the defendants who appear in that Court as well as ensuring that the criminal justice system takes seriously the concerns and challenges facing Indigenous communities”. ${ }^{115}$ This approach is endorsed by those involved in the Division such as the Victorian Department of Corrections. They have indicated that re-offending for them is not an indicator of failure and especially not in the case of the re-offending that has occurred in the Koori Court Division as it is often not significant re-offending. ${ }^{116}$ This means that patterns of behaviour have already been modified in a positive sense. ${ }^{117}$

As discussed earlier, the primary aim of the Koori Court Division is to reduce overrepresentation in the criminal justice system of Aboriginal Offenders. ${ }^{118}$ In a qualitative sense, the Court has clearly achieved this. When it comes time to sentence an Offender in the Koori Court, the focus is on rehabilitation and not just rehabilitation through independent programs (which are utilised also) but actually acknowledging in court what the context of the offending is and showing some understanding of it. Thus, rehabilitation is privileged by its integral role in the Court process. Rehabilitation is done in the hope that it will reduce overrepresentation. This is particularly important when the context of the offending is specific to Aboriginal people such as being a member of the stolen generation ${ }^{119}$ or being socially and economically disadvantaged. ${ }^{120}$ In these instances, the context-based approach strongly supports the Court's complimentary aim of "the incorporation of Aboriginal people in the legal process to better facilitate an ethos of recognition" ${ }^{121}$ by recognising problems specific to Aboriginal culture and dealing with them in a collaborative way. This approach is also validated by Aboriginal commentators, particularly Larissa Behrendt, in her characterisation of an Aboriginal approach to dispute resolution, which includes co-operation and egalitarianism, ${ }^{122}$ both of which are necessary in a collaborative approach. All the Magistrates who participate in the Koori Court Division are amenable to this approach, understand its reasoning, and support it. ${ }^{123}$ This is obvious in all the cases I observed, but was particularly obvious in the following examples:

1) An Offender appeared before the Broadmeadows Koori Court Division in July 2003; he was charged with property offences on a separate list but was before the Koori Court Division because he was in breach of an order which was part of a sentence he was given there. It was the first noncustodial sentence he had ever received in a long history of engagement

\footnotetext{
${ }^{115}$ Richard Edney, The Koori Court Division of the Magistrates' Court of Victoria: Philosophy, Aims and Legislative Scheme, 3 BOURKE’s C.L.N.V. 6, 51 (2003).

${ }^{116}$ CORRECTIONS REPRESENTATIVE AT TWO YEARS ON-HOW GOES THE KOORI COURT, supra note 13.

${ }^{117} \mathrm{Id}$. and INTERVIEW WITH SANDRA ROBERTS, supra note 76.

${ }^{118}$ DEPARTMENT OF JUSTICE, supra note 1.

${ }^{119}$ HUMAN RIGHTS AND EQUAL OPPORTUNITY COMMISSION, supra note 29 and see also Richard Edney, The Stolen Generation and Sentencing of Indigenous Offenders, 5 INDIGENOUS L.B. 23 (2003).

${ }^{120}$ See e.g., Neal v The Queen, (1982) 149 CLR 305 (High Court of Australia, 1982).

${ }^{121}$ Harris, supra note 35, at 7.

${ }^{122}$ BEHRENDT, supra note 10, at 49. Note that Behrendt also considers self-determination to be a necessary element in the success of Aboriginal dispute resolution.

${ }^{123}$ INTERVIEW WITH MAGISTRATE JOHN MURPHY, supra note 76.
} 
with the criminal justice system. Instead of simply looking at the breach, which potentially could have seen him back in jail, the Magistrate, working with the AJO, the Offender's sister who was present at the table, the Corrections officer who was familiar with the Offender and a member of the body of the Court (a Koori Prison Worker who has had contact with the Offender in prisons), pinpointed the Offender's problems as being strongly related to where he was living. Consequently, the Offender was placed on a Community Based Order (CBO) which stipulated that he must reside outside Melbourne with his mother and make all further appearances at the Shepparton Koori Court Division as part of the fulfilment conditions. This as an example not only of the Court using imprisonment as a last resort but also of the Division putting the offending in context. This particular Offender had been a member of the stolen generation. The impact of this on his life was fully recognised by the Division, as was the role played by his substance abuse problems.

2) An Offender appeared before the Shepparton Court in July 2004 charged with unlawful assault. The Division's examination of the context of his offending was assisted greatly by the Offender's support person. His situation and background were thoroughly assessed. This lead to the revelation that he had been drinking alcohol since he was five years old and that he was having a lot of trouble dealing with a custody issue with a previous partner. He had not been able to see his children and this had been a huge strain. Although this story came out slowly and in an erratic fashion, there was no sense that there was a time limit on the process. ${ }^{124}$ The fact that he had recently withdrawn an appeal against sentence in the County Court and was soon to be commencing a jail term was noted. The Court therefore focused on his alcohol problems and what could be done about them within the structure of a community based order, which it will be necessary for him to serve once he is released from prison. The case caused great emotion in the courtroom and there was a sense that the Offender had talked about his problems in a way that he perhaps hadn't done before. This comment is made by many involved with the Court: that because of the way the Court operates, Koori people feel they can "open up" before the Court in a way they would not in a normal court. ${ }^{125}$ This not only indicates that the Court is facilitating its aim of rehabilitation but also indicates that the Court is, in some ways, fulfilling its aim of cultural appropriateness and inclusion.

\footnotetext{
${ }^{124}$ Time not being an issue is another of the characterisations Behrendt makes of Aboriginal dispute resolution. See supra, note 10 at 49 .

${ }^{125}$ InTerview With Dale AtKinson, Client Services OfFicer, Victorian Aboriginal Legal SERVICE (ShePparton), PHONE INTERVIEW (Jul. 14, 2004) and INTERVIEW WITH SANDRA RoberTS, supra note 76.
} 
Aside from the rehabilitative function of the Division, on a more basic level, it is fulfilling its aim of reducing the overrepresentation of Aboriginal people in the system (specifically the prison system) by diversion. Prison sentences are rarely handed down by the Koori Court Division at Broadmeadows or Shepparton, though it has occurred on occasion. This diversionary approach is not taken simplistically; it is done with an understanding of why this approach is taken and why it is better. This is evidenced by a case discussed earlier where the Magistrate who was considering imprisonment, asked the AJO for an opinion and was told that "He does jail easy, jail wont do him any good”. Her subsequent sentence was an innovative response to this, which was a difficult task due to a perceived lack of appropriate rehabilitative programs for the particular Offender. Further strength of the diversionary approach in the Koori Court Division is evidenced by the fact that two Magistrates and many other participants in the Court are now advocating that the diversionary, "therapeutic", approach should be incorporated into all courts. ${ }^{126}$ This clearly shows strong commitment to the concept, rather than just the act of diversion.

Perhaps one of the most interesting, challenging and oblique aims of the Division is that of community building, involvement and to some extent, control. One of the biggest factors affecting this particular aim in a practical sense is geographical location. ${ }^{127}$ This is because in some locations, such as Shepparton, there is an already strong Aboriginal community, ready, willing and able to become involved in a project like the Koori Court Division. In other locations, such as Broadmeadows, the community is not all in one place and is not organised into groups whose structure is able to so readily be involved in such a project. In looking at how this aim was fulfilled, the way that "community" was conceived must also be examined. As discussed earlier, there is a problem with the perception of urban Aboriginal communities in that they are regarded as having lost some or all of their culture, and an attendant belief that they may not be as strong. As Behrendt and Onus have pointed out, ${ }^{128}$ this is not valid. Similarly, Benjamin Richard Smith makes the point that viewing "real" Aboriginal culture as only that which is traditional, is implicit white privileging of traditionality. This means that such a perception is a classic example of the dominant discourse once again inscribing Aboriginal people with its own knowledge about what the meaning of Aboriginality is and how Western textual representations have become the measure of Indigenous authenticity, ${ }^{129}$ rendering Aboriginal people and culture as the "other".

\footnotetext{
${ }^{126}$ INTERVIEW With MAgistrate John MURPhy, supra note 76, Mark Brown, Magistrate bids fond farewell, SHEPPARTON LEADER, July 7, 2004, Various participants at TWO YEARS ON-HOW GOES THE KOORI COURT, supra note 13. See also,

<www.magistratescourt.vic.gov.au/CA256CD3001D864/page/Court+support+Diversion+services> (last visited Jul. 4, 2005) for detail of other Magistrates' Court programs evidencing the therapeutic justice approach such as the CREDIT program and the Special Needs List at the Melbourne Magistrates' Court. ${ }^{127}$ INTERVIEW WITH TERRIE STEWART, supra note 51, INTERVIEW WITH DANIEL BRIGGS, supra note 39, HARRIS, supra note 35.

${ }^{128}$ BEHRENDT, supra note 10, at 76 and Onus, supra note 106.

${ }^{129}$ Aileen Moreton-Robinson, Introduction: resistance, recovery and revitalisation in Grossman, supra note 106 , at 130 .
} 
Despite the concerns outlined above, there are various ways in which the Division is fulfilling the community building aim. It is evident from observing the courts sitting, particularly in Shepparton, that it is happening. This is shown at a most basic level by simple indicators like many of the Aboriginal people in the Court knowing one another. ${ }^{130}$ Similarly, it is indicated by the fact that Uncle Colin, a Shepparton Elder, is able to trace almost every Offender's family to someone he knows (which in itself has a powerful effect, when he explains to the Offender how the person's relative would feel about the Offender's conduct).

Leaving aside the problems of how community and culture are conceived as discussed above, there is little evidence in my observations of the operation and practice of the Koori Court Division to show that any kind of distinction or even any kind of definition at all was used in deciding who or what was the community. This avoids the dangers discussed to a large extent at the level of assessing the practice of the Division. Observation of the Court process also answers many of the concerns. In looking at the fulfilment of the "community building” aim, it is important to recognise that it is closely tied to recognition and respect for culture, ${ }^{131}$ in that the Court must first recognize the culture upon which the community is founded for the community building aim to be fulfilled. When the Shepparton and Broadmeadows Courts were opened, they both underwent a smoking ceremony; this has great significance for many involved with the Court, particularly the Elders, who then impress it upon anyone who they think needs a reminder of its significance. ${ }^{132}$ Similarly, the traditional owners of the land upon which the respective Courts sit are acknowledged at the start of each sitting, an act which has significance for Aboriginal people and the broader community. ${ }^{133}$

The very presence of the Elders in the Court also has huge significance in terms of recognition and therefore community building and is clearly one of the most progressive and effective elements of the Court. The placement of the Elder at the table with the Magistrate and the recognition this affords for their place within Aboriginal culture and community is integral in fulfilling the Court's aims of community building, involvement and control. ${ }^{134}$ It is also important that the Elders who sit on the Court are being paid. ${ }^{135}$ There have been other instances of Elders sitting on courts as advisers, ${ }^{136}$ but this is the first time that it has been validated by legislation and done on a non-voluntary basis. Though this may seem to be a mere practicality, and is unfortunately turning out to be one that is causing some problems for

\footnotetext{
${ }^{130}$ PERSONAL OBSERVATIONS ON VARIOUS DATES AT THE BROADMEADOWS AND SHEPPARTON COURTS

${ }^{131}$ INTERVIEW WITH DANIEL BRIGGS, supra note 39.

132 Personal observation of the Shepparton Koori Court (Jul. 9, 2004) and Two Years OnHOW GOES THE KOORI COURT, supra note 13.

${ }^{133}$ DR WiLliam JONAS, RECOGNISING ABORIGINAL SOVEREIGNTY - IMPLICATIONS FOR THE TREATY Process, PAPER Presented at ATSiC NATional Treaty Conference (August 2002).

${ }^{134}$ EVIDENCE GIVEN BY KATE AUTY TO STANDING COMMITTEE ON ABORIGINAL AND TORRES STRAIT Islander AFFAIRS, PARLIAMENT OF AUSTRAliA (House OF RePRESENTATIVES) (Feb. 17, 2003), available at <http://www.aph.gov.au/house/committee/atsia/indigenouscommunities> (last visited Jul. 25, 2004).

${ }^{135}$ AUTY \& BRIGGS, supra note 34

${ }^{136}$ GOLD COAST COMMISSION ON NATIVE COURTS, REPORT OF COMMISSION ON NATIVE COURTS (1951) and INTERVIEW WITH MAGISTRATE JOHN MURPHY, supra note 76.
} 
the Elders, ${ }^{137}$ the symbolic value of payment by the system for the cultural knowledge that the Elders possess is significant.

The impact that the Elders have on Offenders who come to the Court is palpable and is a strong indicator that through recognising the importance of the person who is "shaming" them (the Elder) culture is also recognised, which then helps to strengthen community. To make such a connection may seem somewhat oblique, but as Daniel Briggs (Koori Justice Officer at Shepparton) has commented when asked if the Court was facilitating community building, "it may not be so visible but it's there". ${ }^{138}$ Daniel Briggs is a member of the Aboriginal community at Shepparton so his comments on this topic are very useful. His perception indicates that it is a difficult aim to assess and can't be done by reference to concrete facts but rather "the feeling" of what is happening in the Court. In particular, as discussed earlier, it can not be done by measuring the community against the presence of what are regarded as "traditional" aspects of Aboriginal culture. The reaction to the Elders by Offenders is indicated by comments such as "In our culture we've got to respect the Elders. So by putting them in (the Court) it makes the person have a lot more respect". ${ }^{139}$

Many participants experience an emotional response to the Elders. Most of these responses are inspired by "shaming", ${ }^{140}$ which is when an Offender is spoken to by the Elder about the ramifications of their behaviour. It is one of their most significant roles in the Court. Importantly, "shaming" seems to be considered by some Elders involved in the Court as a partial recognition of Aboriginal law. ${ }^{41}$ Unfortunately, although most participants in the Court assess Offenders' reactions to the Elders as being positive and therefore leading to a positive assessment of the Court's role in community building, some are more cautious. A Corrections representative, who deals with the Offenders after their Koori Court appearance, has said that though the reaction to the Elders in the Division is tangible, it is not clear that the Offender really carries it out of the Court with them. ${ }^{142}$ This may be something that needs time to develop, and should be viewed in light of other comments by the Corrections representative, such as that it is really too early, from a Corrections perspective, to be conclusively assessing Offenders who have been through the Division's process.

Another important way in which community building is being fulfilled is through the use of Aboriginal service providers in sentencing, although this is a problematic area in some respects. At Shepparton, the Division relies heavily on the local

\footnotetext{
${ }^{137}$ The payment they receive from sitting on the Court is affecting their pension and other social security benefits. The Australian Tax Office has considered whether to grant the payment they receive an exemption which will reverse this effect, but the issue remains unresolved.

${ }^{138}$ INTERVIEW WITH DANIEL BRIGGS, supra note 39.

${ }^{139}$ Jewel Topsfield \& Marc Moncrief, Tough justice or soft touch in Koori Court?, THE AGE, Sept. 4, 2004.

140 Two YeArs ON-HOw GOES THE KOORI COURT, supra note 13.

${ }^{141}$ Id.

${ }^{142}$ INTERVIEW WITH SANDRA ROBERTS (CORRECTIONS OFFICER, SHEPPARTON), supra note 76.
} 
Aboriginal Health Service in formulating sentences which utilise their services. ${ }^{143}$ The local Aboriginal co-operative, Rumbalara, also plays a role, as do various programs run under the auspices of the co-operative, such as the women's mentoring program. However, concern has been expressed by a Corrections representative and the Shepparton Justice Officer that there is insufficient involvement by Rumbalara and its women's mentoring service. Similarly, at the seminar to review the first two years of Shepparton Koori Court Division's operation, ${ }^{144}$ concern was expressed by a member of the Regional Aboriginal Justice Advisory Committee, that there were programs they were trying to set up, such as an Aboriginal working farm where people who had been entrenched in the criminal justice system could gain skills and undergo rehabilitation, but that these programs were facing prejudice in the broader community.

These instances are of great detriment to the fulfilment of the community building aim, particularly the alleged lack of involvement of Rumbalara, an organisation one would suppose would be in an excellent position to support this aim and the Court in general. This is supported by the findings of Dr Mark Harris, whose interim evaluation of the Court asserts that "the involvement of Aboriginal community organisations is an important aspect to the success of any Koori Court" ${ }^{\text {145 }}$. The detriment is also clear in light of the RCIADIC's view of the role of Aboriginal community organisations as crucial in the negotiation with the dominant system for some kind of self-determination.

Most of the above discussion has been weighted towards Shepparton, Broadmeadows presents a different situation. The Offenders who appear before the Boradmeadows Koori Court tend to be drawn from across Australia, meaning that no matter how "community" is defined, it is difficult for one to support Offenders who are new to the geographic area. Similarly, this could have implications if the ownership of the land upon which the Court sits and has jurisdiction over is used as a definitional tool for community and membership thereof. This is countered by indicators that Aboriginal people who have appeared before the courts which are not upon their traditional lands are willing to respect the Court more for that reason. ${ }^{146}$ Although obviously community is a key aspect of Aboriginal culture, it seems from observation that the Broadmeadows Koori Court is still able to impress culture and a sense of community on the Offenders and to utilise both to construct effective sentencing. ${ }^{147}$ This both illustrates and is supported by the assertions made by Behrendt and Onus that urban Aboriginality is still strong. ${ }^{148}$

\footnotetext{
${ }^{143}$ Personal observations on Various dates at the Broadmeadows and SHePPARTON Courts, supra note 25.

${ }_{144}^{14}$ TWO YEARS ON-HOW GOES THE KOORI COURT, supra note 13.

${ }^{145}$ Harris, supra note 35.

${ }^{146}$ Personal observation, Broadmeadows Koori Court (Jul. 20, 2004). An Offender was reminded by the Elders that he should have more respect because he was on lands that he was not the traditional owner of and that consequently, he should have more respect and not behave in the way he had because he was on someone else's lands. The Offender was responsive to this.

${ }^{147}$ Though not as often or palpable, the phenomena of people knowing each other and supporting one another is definitely evident at Broadmeadows. In my observations I witnessed occasions where someone has spoken up from the body of the Court because they want to advocate for, or have
} 
As discussed earlier, the aim of "incorporation of Aboriginal people into the legal process" 149 has been interpreted in various ways. The evaluation of the fulfilment of this aim will look broadly at all of the ways it is being fulfilled, without making the "straight" or "adaptive" incorporation distinction. One of the most important aspects and indicators of its fulfilment is that Offenders who come to the Koori Court Division are not afraid to speak up and become involved in the process. This is highlighted by many participants as one of the most important things that the Division is doing. Offenders are not intimidated by the Court because its adaptation, including the changed seating arrangement, the presence of the Elders, the attempt by the prosecutor and others to simplify the legal language used and the fact that the Court takes significantly longer to hear an Offender's story ${ }^{150}$ have made them comfortable and given them a sense that "they own the Court". ${ }^{151}$ The phenomenon of the legal system being one where "we do not listen and that we have not been very good at making our environments in the legal system open to people" ${ }^{\text {"152 }}$ has been significantly rectified by the way the Koori Court Division operates. An environment where Aboriginal people feel comfortable enough to participate in the court process could also potentially help the Aboriginal community to eventually claim more power over that process. This is then an extremely positive aspect of the Division's operation, considering that this paper argues that the Koori Court Division generally has not devolved sufficient power to Koori people in its development or process.

Another important aspect of the fulfilment of this aim is that Offenders and the Koori community see their culture being given status within the system by the fact that the Magistrate is asking an Elder for advice, thus to an extent, the system is no longer a place where one legal culture is dominant but a place where "The black robe appears to be deferring to the black face". ${ }^{153}$ The above strategies of incorporation are all supplemented by the fact that the Court takes what could be termed a "therapeutic justice" ${ }^{154}$ approach, which is tied to and supports its desire to do things with a "cultural perspective". ${ }^{155}$

information to offer about the Offender. This is a strong indicator of community. Further examples of the community involvment at Broadmeadows is the active involvment of Aboriginal service providers, such as the Kookaburra Club, Aboriginal Health Services and individuals such as Mr Alph Bamblett, who acted as a mentor for an Offender who appeared before the court in July 2003, which had a positive effect on the formation of a sentence for that Offender.

${ }^{148}$ BEHRENDT, supra note 10, at 76 and Onus, supra note 106.

${ }^{149}$ Harris, supra note 35.

150 Elena Marchetti \& Kathleen Daly, Indigenous Courts and Justice Practices in AUSTRALIA (2004).

${ }^{151}$ INTERVIEW WITH DALE ATKINSON, supra note 125

152 EVIDENCE GIVEN TO STANDING COMMITTEE ON ABORIGINAL AND TORRES STRAIT IsLANDER AFFAIRS, supra note 134.

153 MARCHETTI \& DALY, supra note 150.

${ }^{154}$ Although Marchetti and Daly, (id.) argue that the various Indigenous courts developing in Australia, including the Koori Court and the Nunga Court have their own unique version of what is usually termed as therapeutic justice.

${ }^{155}$ INTERVIEW WITH DANIEL BRIGGS, supra note 39. 
Aside from the way in which the Division has fulfilled its specific stated aims, other issues have arisen which are not directly related to the aims. There have been some concerns with service provision for example. Magistrates have at times struggled to construct an order that is appropriate for the Offender; they have been unable to find a program that could help the Offender to make "positive changes in their life". ${ }^{156}$ However, the Division has shown ability to respond to this. On one occasion at Broadmeadows, ${ }^{157}$ this problem arose and was further highlighted by a member of the body of the Division (the director of Aboriginal organisation Maraleek), who stood up to voice his concerns. The particular Offender had been undergoing some informal mentoring from a member of the Aboriginal community and in light of the lack of programs suitable for him, he was simply bailed on the undertaking that he had to bring back to the Division some positive evidence of what he had done to change his life, with the help of his mentor. Although this is a positive example of the Division staying true to its aims even in the face of logistical difficulty, it does highlight a serious resource deficiency. The Division is only able to operate effectively with the partnership of service providers.

Similarly, the issue of the geographical location of the Division in relation to the service providers that it utilises is an issue at Broadmeadows, and is of great concern to its AJO, Terrie Stewart. Terrie points out that although the Division is in the Western suburbs, many of the service providers are based in the Northern suburbs. This significantly reduces the chance of an Offender successfully completing their order $^{158}$ and undermines the effectiveness of the Division's ability to rehabilitate Offenders.

There is evidence of some problems with Magistrates who sit on the Division. On the whole, most participants in the Division commend the efforts of Magistrates in adapting to the different procedures of the Court. However, there are apparently some Magistrates whose inability to adapt severely hinders the operation of the Division and have at times apparently made things "confusing", ${ }^{159}$ which is something the Division strives to avoid. This indicates that Magistrates must be chosen very carefully for participation in the Koori Court Division. In addition, as Dr Mark Harris has outlined in his report, it is important that the Magistrates sitting in the Koori Court Division remain a small and continuous group so that relationships can be developed with the Elders and other Court personnel. ${ }^{160}$

How an Offender is transferred from the mainstream to the Koori Court Division also presents some problems. Essentially it rests upon the Offender's legal representative to apply to have their client transferred to the Division. They are eligible or not eligible for this based on a set of criteria laid out in s $4 \mathrm{~F}(1)$ of the Magistrates Court (Koori Court) Act 2002 (Vic). These criteria are unproblematic. However, it has been indicated that knowledge of the Koori Court Division primarily relies

\footnotetext{
${ }^{156}$ Id.

${ }^{157}$ Personal ObSERVATION OF the Broadmeadows Court (Jul. 20, 2004).

${ }^{158}$ INTERVIEW WITH TERRIE STEWART, supra note 51.

${ }^{159}$ INTERVIEW WITH SANDRA ROBERTS, supra note 76.

${ }^{160}$ Harris, supra note 35 at 28-29.
} 
upon "word of mouth". ${ }^{161}$ This raises an issue of equality of opportunity in that if an Aboriginal Offender's legal representative does not know about the Division, then it is highly unlikely that the Offender will have the opportunity to have their matter heard there. Of course this issue is dealt with to a large extent by the fact that many Aboriginal Offenders will have legal representation from the Victorian Aboriginal Legal Service, who are aware of the Division. The situation is also dealt with in Shepparton by the fact that it is a small community so "word of mouth" proliferates and publicises more effectively. However, the situation in Broadmeadows is very different and perhaps indicates that the system of referral to the Koori Court Division needs to be more comprehensive. ${ }^{162}$

There are many positive features of the Koori Court Division's operation and overall, it is fulfilling its potential to be responsive and inclusive of the Koori community in a procedural sense, to the extent that this was envisaged by the development process. Most importantly, the role of the Elders is strong and despite the deficiencies in devolution of power to the Koori community, they are prominent participants in the Division's process.

\section{ANSWERING COMMON CRITICISMS OF THE KOORI COURT DIVISION}

Since its inception, the Koori Court Division has faced criticism. Many of these criticisms are based on a misunderstanding of what the Division does and is. The most persistent criticisms only will be dealt with here. One of the most recurrent and prevalent has been that the Division is a "soft option"163 This criticism misunderstands firstly, that the Division does not act under a special sentencing regime and does not offer special "soft" treatment but different, culturally appropriate treatment. In addition, it has become clear that for the bulk of Offenders, going to Court and talking about and facing up to their problems and the root causes of their offending is much more difficult than either going to jail or going to a mainstream court. ${ }^{164}$ In a mainstream court, the process was largely alien, confusing ${ }^{165}$ and the Offender was essentially disassociated by the process, it was therefore a meaningless exercise. The difficulty in facing the Koori Court Division was clearly evident in a recent case at the Shepparton Court, where an Offender was forced to confront family issues, alcohol use and the status of his relationship. He was reluctant at

\footnotetext{
${ }^{161}$ INTERVIEW WITH TERRIE STEWART, supra note 51.

${ }^{162}$ Note that No.32 of IN BRIEF, the fortnightly newsletter of the Victorian Bar Council (available at $<$ http://www.vicbar.com.au/WebData/pdf/InBrief302.pdf>, last visited Jul. 2, 2005) publicises changes to the way the Koori Court List will operate at Broadmeadows, indicating that this problem is being addressed to an extent.

${ }^{163}$ See, e.g., Carly Crawford, Koori Courts too soft, THE Sunday Herald Sun, Aug. 8, 2004; Court a Joke, WARRNAMBOOL STANDARD, Jul.14, 2004; Topsfield \& Moncrief, supra note 139.

${ }^{164}$ See, e.g., INTERVIEW WITH DANIEL BRIGGS, supra note 39, Harris, supra note 35, INTERVIEW WITH TERRIE STEWART, supra note 51.

${ }^{165}$ Tauri D'Eatough, A Day in the Life of an Aboriginal Legal Service Lawyer, 25 INDIGENOUS L.B. 17 (2002).
} 
first, but in the end he had faced those issues and the difficulty in doing this was indicated by his highly emotional state in the courtroom. ${ }^{166}$ Similarly, comments like the following, by Offenders who have been in front of the Court dispel the "soft option" myth:

Well in the Koori Court like you feel like the size of an ant. When they talk to you, you do, you start getting a lump in your throat, you feel like you know, crying, I've cried even in there, and they make you try to understand, we're not above the law, and we get up and say what we have to say about ourselves, and they listen to what we say and feed back what they want to say to the ones that have been in trouble by the law. ${ }^{167}$

Another misunderstanding perpetrated by this view is that imprisonment is the only option in dealing with Offenders. It seems this criticism stems from a belief that the Division is unwilling to ever deal out prison terms, and that therefore its penalties are "lenient". ${ }^{168}$ A view such as this completely overlooks the work of the RCIADIC and other evidence which shows that "Aborigines suffer disproportionately as a result of contact with the agencies of criminal justice administration",169 and that under these circumstances, imprisonment should be a sanction of last resort. ${ }^{170}$ Perhaps the most effective, though simplistic answer to people who are willing to overlook such factors is to point out that the Court does still hand down custodial sentences if it becomes necessary. ${ }^{171}$ Also, it should be pointed out that the Elders are by no means "soft" when they address an Offender, with their approach being characterised in terms such as "dressing down or a ripping". ${ }^{172}$ Kate Auty, the original Shepparton Koori Court Magistrate has also recounted incidents where she has had conflict with Elders who thought the Offender's conduct warranted a tougher sentence than she did. ${ }^{173}$ Terrie Stewart, the Broadmeadows AJO, has spoken of how it is clear that Aboriginal people are often tougher on Aboriginal people than the criminal justice system might be. ${ }^{174}$ The above discussion demonstrates that the criticism of the Koori Court Division as a "soft option" is both wrong in its basis, but that even if its basis was correct, it is also substantially incorrect.

Though Warnambool is not dealt with in this paper, the following aspect of its operation is relevant to this discussion. The soft option criticism as it has been expressed in Warrnambool ${ }^{175}$ introduces a challenge for the Division in terms of attitudes towards in the broader community. In some ways this will be the most

\footnotetext{
${ }^{166}$ Personal OBSERVATION OF THE SHePPARTON Court (Jul. 9, 2004).

${ }^{167}$ THE LAW REPORT, supra note 58.

${ }^{168}$ Court a Joke, supra note 163.

${ }^{169}$ LUKE MCNAMARA, ABORIGINAL HUMAN RIGHTS, THE CRIMINAL JUSTICE SYSTEM AND THE SEARCH

FOR SOLUTIONS: A CASE FOR SELF-DETERMINATION (1993).

${ }^{170}$ ROYAL COMMISSION INTO ABORIGINAL DEATHS IN CUSTODY, supra note 10, recommendation 92

${ }^{171}$ AUTY \& BRIGGS, supra note 34.

${ }^{172}$ Kate Auty in THE LAW REPORT, supra note 58.

${ }^{173} \mathrm{Id}$.

${ }^{174}$ INTERVIEW WITH TERRIE STEWART, supra note 51.

${ }^{175}$ Court a Joke, supra note 163.
} 
fundamental challenge the Court must face as many people's views would predicate a negative reaction to a project such as this. It is interesting to note that the criticism in Warnambool, as expressed in the media, has come from the police department (although anonymous). This did not occur in Broadmeadows and particularly not in Shepparton, where Police Prosecutor Gordon Porter is one of the Court's greatest supporters $^{176}$ and where the Shepparton Police Chief Inspector Graham Wigg invited his officers to put an anonymous note under his door with any "grizzles, gripes, bitches, whinges” about the Court and received only one note. ${ }^{177}$

It is arguable that the difference in perceptions of the Court at Warnambool and elsewhere is due to the process that established them in their respective locations. Both Shepparton and Broadmeadows underwent significant development processes, including cultural education. ${ }^{178}$ There is no evidence to show that such a process was undertaken in Warnambool. This shows the positive impact which education can have on shaping peoples attitudes towards the Court and is a tactic which should perhaps be used more in the establishment and continuing operation of the courts.

Another major criticism of the Court is that it is unfair to have such an option for one particular ethnic group but not another. This criticism was leveled most prominently by David Galbally QC, who attacked the Court at its inception saying essentially that he felt in a multicultural society it's crucial that there be one justice system that can speak to, listen to, deal with fairly and pass sentence on all citizens. ${ }^{179}$ This criticism can be answered in many ways. Firstly, as Kate Auty has pointed out, David Galbally made this criticism with little to no knowledge of how the Court would operate. ${ }^{180}$ Interestingly, he has since reviewed his comments and come to the conclusion that "maybe it is working, maybe my views were wrong". ${ }^{181}$ Secondly, the existence of the Koori Court Division does not preclude the establishment of a similar Division for other cultures and indeed many participants connected with the Koori Court Division have advocated this. ${ }^{182}$ The other main argument against Galbally's comment is that the Division has been established because Aboriginal people have suffered such a persistent and extended history of abuse, misunderstanding and alienation from the criminal justice system and they are still suffering the ramifications of this today in their overrepresentation in the system. Therefore, they are logically and fairly first in line to have this addressed. Finally, it is worth pointing out that in many ways this is a case of one system speaking to and listening to its citizens. His focus on retaining one system perhaps indicates that he feels the establishment of the Koori Court Division is in some way contributing to the creation of a dualist legal system. The Koori Court Division is well short of being this but Galbally's fear seems to be indicative of the protection-

\footnotetext{
${ }^{176}$ See, e.g., FAX/LETTER FROM SERGEANT GORDON PORTER TO INSPECTOR WIGG, supra note 42.

177 Topsfield \& Moncrief, supra note 139.

${ }^{178}$ Harris, supra note 35.

${ }^{179}$ David Galbally, Koori Court tips scales, HeRALD Sun, Mar. 13, 2003.

${ }^{180}$ AUTY \& BRIGGS, supra note 34; THE LAW REPORT, supra note 58.

181 Topsfield \& Moncrief, supra note 139.

${ }^{182}$ TWO YEARS ON-HOW GOES THE KOORI COURT, supra note 13.
} 
ist stance that some take towards the legal system, highlighting another attitudinal problem which the Division must face.

Criticism is also leveled at the Court that because of the requirement that an Offender must plead guilty to participate ${ }^{183}$ the Court will encourage people to plead guilty when they aren't. This criticism is not as easy to answer as the previous two criticisms as there has been some evidence of Offenders pleading guilty so their case will be transferred to the Koori Court Division. ${ }^{184}$ To some extent, this danger is mitigated because of the process of the Court in telling the whole story surrounding the offending. This renders it is less likely that an Offender would be able to plead guilty if they weren't. However, the danger does still remain and although the telling-the-whole-story approach mitigates this to an extent, whether the Offender is guilty or not is certainly not the purpose of telling the story and it is therefore still fair to say that the Division needs to be more aware of whether Offenders are making false guilty pleas.

It is possible that extending the operation of the Division to contested matters could avoid the problems discussed above regarding false guilty pleas. However, when asked about whether the Division could be extended to contested matters, the answer from the participants I interviewed was overwhelmingly negative, barring one interviewee who raised the possibility that if Koori offenders were found guilty after a contested hearing in a mainstream court, the sentencing part of their trial could then be transferred to the Koori Court Division. ${ }^{185}$ The fact that the Division is limited to guilty pleas and the unwillingness to extend it to contested matters has implications for the question of power and the approach of the system toward the Aboriginal community generally. If the Koori Court Division was an initiative that was successful in enabling Aboriginal people to claim power in the court process, as some evidence has shown it to be, then it would be an extremely positive step to extend it to contested matters, where hopefully the same claim for power would be made. The almost total unwillingness of people involved in the Division to even consider the extension to contested matters is therefore another area where the Division is stopping short of addressing the issue of power.

\section{Conclusion And Where to From Here?}

It will be interesting to see what becomes of the Koori Court Division. In particular, whether the enthusiasm and commitment with which the Broadmeadows and especially the Shepparton Courts were established can be continued. This will have impact on the Division's continued development as it is strongly linked to the attitudinal problem discussed earlier in this paper. If there is no enthusiasm and commitment and the attitudinal problem and a reluctance to address the issue of

\footnotetext{
${ }^{183}$ Magistrates' Court (Koori Court) Act, 2002, s 4F (1) (c) (Vic).

${ }^{184}$ TWO YEARS ON-HOW GOES THE KOORI COURT, supra note 13.

${ }^{185}$ INTERVIEW WITH MAGISTRATE JOHN MURPHY, supra note 76.
} 
power imbalance remain, there will be a danger that the Division will become just another attempt to make the legal system more acceptable. ${ }^{186}$

This paper's primary concern in assessing and evaluating the Courts was inclusiveness and responsiveness to the Aboriginal community and whether the Division devolves any real power to the Koori community. It is clear that at the development stage (which was largely done at Shepparton) some consultation with the Koori community did occur. Procedurally, this consultation has continued, most successfully in the role of the Elders in the Division's process. A challenge for the Division will be to replicate this in other locations. This challenge has been highlighted by the backlash to the Court at Warrnambool, which this paper argues may be due to lack of education about the Court in the process of establishing it. This is extremely detrimental to the Division and not a good indicator for its potential in terms of being extended to other locations. The experience at Warrnambool may point to a need for the same development process as that which occurred at Shepparton, to be implemented whenever a new Koori Court Division location is established.

Not only must the Court be carefully established in new locations but conceptually it must continue to develop also. It may be necessary to consider whether the Division should remain as a specialist court, considering that maintaining the distinction between "normal" and "specialist" courts limits the potential to challenge the effectiveness of fundamental aspects of the legal system, such as its adversarial nature. ${ }^{187}$ Also, though the Court is a progressive and innovative approach, it still has the potential to further address problems with Aboriginal people's interaction with the legal system. Most prominently, there is potential for it to address the issue of power further and its operation could be used to improve the relationship between Aboriginal people and police, considering that police have most active involvement with prosecutions within the Magistrates' Court's jurisdiction. The Division must also continue to develop in a way that is wary of the criticism it faces, lest a backlash against it occur which may then render it politically less palatable. Nonetheless, the imperative of the continued development of the Division must be that more power is devolved to the Koori community in order that they may play a more equal role in the development and procedure of the Koori Court Division and so that the Division can play a stronger role in rectifying the subjection of Aboriginal people.

\footnotetext{
${ }^{186}$ BEHRENDT, supra note 10, at 49.

${ }^{187}$ FRIEBERG, supra note 112, at 14
} 